DOI: 10.1515/afmnai-2016-0022

UDC: $811.111 ' 276.6: 61$

Professional article

\title{
Teacher Education in English for Special Purposes
}

\author{
Zorica Antić \\ University of Niš, Faculty of Medicine, Niš, Serbia \\ SUMMARY
}

This paper establishes a basic framework for addressing the issue of teacher's role and education in English for Special Purposes (ESP) with an overview of English for Medical Purposes (EMP).

The content of an ESP/EMP syllabus is determined by the learners' reasons for learning English. This has led to a change in the role that teachers have in specialized English classes compared to general English. They are required to work actively with the learners and medical subject teachers in order to create a syllabus that would promote effective learning.

Teacher education encompasses adequate knowledge, teaching and professional skills, interests and attitudes towards teaching.

Key words: English for Special Purposes, medical students, teachers' roles, education 


\section{INTRODUCTION}

Effective English language education has become essential in our globally connected world. English for Special Purposes (ESP) is an approach to language teaching and learning which is based on learners' needs. In other words, decisions concerning the content and methods are based on the learner's reasons for learning (1).

The primary question in ESP course design is why the learners need to learn English. The awareness of this need will influence the content of the language course. ESP is related to situated language use, therefore need analysis represents the primary step in ESP course design. For that reason, it is said that these language courses are student-centered, i.e. students have a key role in determining what they are going to learn. Need analysis provides information about the situations in which learners will be using the language $(2,3)$. For example, in English for Medical Purposes (EMP), these situations may refer to doctor-patient communication, technical language used in various medical documents such as lab reports, conference language, presentations, writing research articles, case studies, etc.

Teaching English for Specific Purposes, in other words education for specialized English, is seen as something different from teaching general English. ESP teachers need a variety of skills that are not restricted to teaching methodology. Among other things, these skills include some basic knowledge of their students, the particular subject area, course design, material production, organization, etc. Teachers are expected to have a well-developed understanding of, or intellectual curiosity about, the object of their teaching. Language content of ESP courses usually differs from general English in that it acknowledges that, for example, students of medicine wish to improve their proficiency in medical English discourse and it is, therefore, natural that the content of the medical English language course reflects the linguistic features of the discourse.

\section{Teacher's roles in ESP}

The quality and degree of learner achievement are mostly determined by teacher competence and motivation. A combination of teaching skills, pedagogical theory and professional skills serve to create the right knowledge, attitude and skills in teachers. Teacher education in ESP is a continuous process and it goes on throughout professional life. It includes improving the general educational background, increasing the knowledge of the students' subject area, understanding the nature of the learners, and the development of practical skills and competences $(4,5)$.

ESP teachers can have several roles among which are teaching, course designing, providing materials, collaborating, researching, and evaluating. ESP is a practical discipline and its most important objective is to help students to learn. Contrary to the traditional roles, ESP teachers are not the primary vessels of knowledge. The students may know more about the content than the teacher, and their knowledge of the content can be used to generate communication in the classroom. Here, the teacher's role is that of an advisor or a counselor who possesses knowledge of communication practices and negotiates with students on how these practices can best be applied to meet the teaching objectives. This means that teachers need to be flexible, willing to listen to their students, and take active interest in their subject area (5).

It is often the case that a textbook cannot adequately meet students' needs, so teachers have to provide additional material for the course. This process involves selecting and adapting available material, as well as assessing its effectiveness. In English for Medical Purposes, additional material may be in the form of medical documents, case studies and case reports, research articles, medical records, laboratory findings, etc. It can be beneficial to include students in this process, whose task would be to bring the material from their medical subjects. This is one of the ways in which learning language is contextualized, it is related to the basic studies and the students are able to perceive the link and understand how language is actually used in their future professional situations.

Teachers are also researchers in the sense that they investigate specific medical genres, language and skills involved in specialized communication. After the need analysis has been conducted, the next step is incorporating the findings obtained from research into course design and material preparation.

Another important role of ESP teachers in that of a collaborator. It refers to establishing a good cooperation with both students and subject-specific teachers. Team teaching is one of the very important postulates in ESP, and it is crucial for a successful course. It introduces the necessary contents and promotes the relationship of the participants in a three- 
way dialogue (6). In addition, it also integrates medical knowledge and English language teaching. Students learn the language in context and they are motivated to apply the medical knowledge they possess during language classes (7). Furthermore, the cooperation is also beneficial for medical teachers who are essentially doctors very often without any formal training in pedagogy and teaching process. Namely, they have an opportunity to learn from the language teacher about the teaching methods and approaches and use this knowledge in their regular classes. Therefore, this aspect of team teaching is very important as it offers a myriad of opportunities for the development of all the parties included.

\section{Teacher education in EMP}

As a complex and demanding intellectual work, teaching cannot be accomplished without appropriate preparation. Teacher education is related to proficiency and competence and encompasses adequate knowledge, teaching and professional skills, interests, and attitudes towards teaching. The problems that may develop are often related to the selection of materials, the use of appropriate methods and techniques, determining the basic organizing principles, considering the target situations in which the students will need the language, meeting students' needs, creating a setting that is of interest to students and which would encourage them to participate in activities. This further leads to effective lessons and greater level of learning (8).

One of the very important questions in ESP is the level of knowledge teachers should have of their students' specific medical subjects. EMP, like other areas of ESP, is content- and context-based. Therefore, it is inevitable to consider the extent of knowledge language teachers should have of medical subjects. Since the course aims at developing language and skills in the context of medicine, it is natural that language teachers should possess at least some general knowledge of their students' major subjects. Teachers can take advantage of their linguistic background as well as use their students' knowledge of medicine that they bring to the classes. A combination of all these elements will provide a solid ground for successful learning (9).

Teaching medical English can be exciting and unpredictable. Teachers can experiment with various approaches in order to effectively help learners to achieve their learning goals and learn what they actually need and will be using in future professional situations. The central principle is to grasp the bigger picture of medical English, what is involved in teaching medical English learners and the structure and content of the courses. It involves understanding who the learners are, what they are going to be taught and how they are going to be taught (10).

The learners in our medical English classes are students of medicine whose English lessons are elective ( $1^{\text {st }}$ year students) and obligatory ( $2^{\text {nd }}$ year students). Although the course requires them to have at least an intermediate level of English language knowledge, very often this is not the case and the groups can be heterogeneous. Their medical knowledge may also vary depending on interests and aspirations.

The course focuses on the learners' needs and it will most likely include medical vocabulary and medical skills and these are the most likely areas to be taught in a medical English course. The medical vocabulary may refer to various aspects, such as specific prefixes and suffixes, medical-lay equivalents, technical terms used in communication with colleagues or everyday expressions used in communication with patients. Medical skills may include presentations, reports, doctor-patient communication, taking medical history, writing research articles. The skills are those things that future medical professionals will be doing in their careers. These represent the main content of a medical English course. For example, a lesson focusing on medical skills includes teaching functional language related to the skill, such as useful phrases for participating in presentations. Medical skills are linked to language skills and in the case of oral presentations, the linguistic aspect would include practicing fluency and listening. The third important element is language systems specific to the medical skill, e.g. pronunciation and intonation (2).

Activities in EMP courses are most often conducted in groups and pairs, and this form of interaction promotes mutual cooperation, team work, and shared learning (4).

\section{CONCLUSION}

In ESP, language teaching and subject matter are integrated. This is a motivating combination because students are given an opportunity to apply what they learn in English classes to their fields of study. The process is reciprocal and the students may 
use their knowledge of the major fields to improve the ability to learn English. For example, in EMP, the knowledge of medicine provides the relevant context that they need in order to understand the English of the classroom. Students learn how individual aspects and topics from the field of medicine are expressed in English and they are able to immediately use what they learn in EMP course.

Medical English is an area that offers numerous opportunities for teacher education and development not only to the language teachers but also to medical teaches. They can learn from one another - language teachers can broaden their understanding of medicine whereas medical teachers may develop their teaching practices and use the methodology of language teaching to improve and enrich their subject-specific classes.

The field of teacher education is wide-ranging and teacher development is a continuous process of transforming potential into performance. As such, it requires extensive exploration and study. The paper offers a basic framework and introduces the initial aspects, setting the ground for further studies which would deal with the topic in more detail from the standpoint of both language and medical teacher education.

\section{References}

1. Nunan D. Language Teaching Methodology: A Textbook for Teachers. Phoenix ELT, London, UK, 1995.

2. Saragih E. Designing ESP Materials for Nursing Students Based On Needs Analysis. International Journal of Linguistics 2014; 6: 59-70. http://dx.doi.org/10.5296/ijl.v6i4.5983

3. Long MH. Methodological issues in learner needs analysis. In M.H. Long (Ed.), Second language needs analysis. Cambridge: Cambridge University Press, 2005.

http://dx.doi.org/10.1017/CBO9780511667299.002

4. Stein SG. Equipped for the future: A customerdriven Vision for Adult Literacy and Lifelong Learning. Washington DC: National Institute for Literacy, 1995.

5. Jackson J. . An inter-university, cross-disciplinary analysis of business education: perceptions of business faculty in Hong Kong. Eng Speci Purp 2005; 24: 293-306.

http://dx.doi.org/10.1016/j.esp.2004.02.004
6. Antic Z. Benefits of Student-Centered Tandem Teaching in Medical English.SrpArh 2015; 143: 500-4.

http://dx.doi.org/10.2298/SARH1508500A

7. Antic Z. FactaUniversitatis (Medicine and Biology). 2008; 15: 125-9.

8. Pilott M. How to Teach a Language.XLIBRIS.New Zealand, 2013.

9. Brown JD. The Elements of Language Curriculum.Heinle\&Heinle Publishers, Boston, Massachusetts, USA, 1995.

10. Harmer J. The Practice of English Language Teaching.Longman Handbooks for Language Teachers, London, UK, 1996.Chrousos GP. Stressors, stress, and neuroendocrine integration of the adaptive response. The 1997 Hans Selye Memorial Lecture. Ann N Y Acad Sci 1998; 851:311-35. 


\title{
Obrazovanje nastavnika engleskog jezika struke
}

\author{
Zorica Antić \\ Univerzitet u Nišu, Medicinski fakultet, Niš, Srbija
}

\section{SAŽETAK}

Ovaj rad postavlja osnovne okvire za razmatranje uloge i obrazovanja nastavnika engleskog jezika struke sa osvrtom na engleski jezik za potrebe medicine.

Sadržaj kursa engleskog jezika struke i engleskog jezika za potrebe medicine određen je razlozima zbog kojih studenti uče jezik. To je dovelo do promena u ulozi nastavnika jezika struke u odnosu na opšti engleski. U okvirima jezika struke od nastavnika se očekuje da prilikom određivanja sadržaja nastavnog plana ostvari aktivnu saradnju sa studentima i nastavnicima stručnih predmeta kako bi učenje bilo što efikasnije.

Obrazovanje nastavnika podrazumeva adekvatno znanje, posedovanje nastavnih i profesionalnih veština, interesovanja i stavova prema procesu učenja.

Ključne reči: engleski jezik struke, studenti medicine, uloga nastavnika, obrazovanje 